\title{
KEANEKARAGAMAN SERANGGA PERMUKAAN TANAH PADA LAHAN GAMBUT BEKAS KEBAKARAN DAN HUTAN LINDUNG DI DESA KASANG PADANG, KECAMATAN BONAIDARUSALAM, KABUPATEN ROKAN HULU, PROVINSI RIAU
}

\author{
Novia Gesriantuti, Retno Trantiati, Yeeri Badrun
}

Prodi Biologi, Fakultas MIPA dan Kesehatan, Universitas Muhammadiyah Riau e-mail: noviagesriantuti@umri.ac.id

\section{ABSTRAK}

Penelitian ini bertujuan untuk mengetahui dan membandingkan keanekaragaman serangga permukaan tanah yang ditemukan pada lahan bekas kebakaran dan lahan hutan lindung. Penelitian ini dilaksanakan pada bulan Maret sampai Juli 2016. Penangkapan serangga permukaan tanah menggunakan metode pitfall trap di tiga lokasi yaitu lahan gambut bekas kebakaran pada tahun 2013 yang belum ditanami tanaman (Stasiun I), lahan gambut bekas kebakaran tahun 2013 yang telah ditanami tanaman akasia (Stasiun II) dan lahan hutan lindung, (Stasiun III). Pada masing-masing stasiun dibuat dua transek, dengan tiga plot pada masing-masing transek. Serangga yang tertangkap diidentifikasi dengan mengamati ciri morfospesiesnya. Serangga permukaan tanah yang ditemukan terdiri 16 genus. Stasiun I ditemukan 12 genus dengan Nilai Indeks Keanekaragaman yaitu 0,87 dan Nilai Indeks Dominansi yaitu 0,15, pada Stasiun II terdapat 9 genus dengan Nilai Keanekaragaman yaitu 0,48 dan Nilai Indeks Dominansi 0,44 sedangkan pada Stasiun III terdapat 10 genus dengan Nilai Keanekaragaman yaitu 0,31 dan Nilai Dominansi yaitu 0,71. Adapun Indeks Kesamaan serangga permukaan tanah adalah 58\%.

Kata Kunci : Keanekaragaman, Serangga Permukaan Tanah, Gambut Terbakar, Hutan Lindung.

\section{PENDAHULUAN}

Penyebaran lahan gambut di Sumatera, khususnya terdapat di dataran rendah sepanjang pantai timur dengan luas 7,2 juta hektar. Riau merupakan provinsi dengan lahan gambut terluas di Pulau Sumatera yaitu $\pm 4,04$ juta $\mathrm{Ha}$ atau $56,1 \%$ dari luas total lahan gambut di Sumatera. Namun demikian selama dua dasawarsa terakhir, konversi lahan gambut terutama menjadi lahan pertanian, perkebunan kelapa sawit dan kayu kertas (pulp wood) diperkirakan telah merusak lahan gambut dengan segala fungsi ekologisnya, selain itu lahan gambut merupakan suatu ekosistem yang unik dan rapuh, karena lahan ini berada dalam suatu lingkungan rawa, yang terletak di belakang tanggul sungai (Mubekti, 2011).

Desa Kasang Padang Kecamatan Bonaidarussalam Kabupaten Rokan Hulu Riau merupakan salah satu Desa yang terdapat kawasan lahan gambut akasia dan lahan hutan alami yang memiliki tanah bersifat gambut. Lahan gambut akasia ini memiliki luas sekitar $300 \mathrm{Ha}$ sedangkan pada lahan gambut alami memiliki luas 7500 Ha. Kawasan lahan gambut akasia ini sering mengalami kebakaran akibat dari perebutan lahan antara perusahaan dengan masyarakat sedangkan pada lahan hutan alami ini juga terletak tidak jauh dari pemukiman warga sehingga sudah mengalami gangguan.

Salah satu gangguan serius yang terus terjadi di lahan gambut adalah kebakaran. Kebakaran sebagian besar terjadi pada lahan gambut sebagai akibat aktivitas pembukaan lahan (Thoha, 2006). Tanah gambut bersifat kering tak balik (irreversible dryng) yang apabila kekeringan dalam waktu lama akan sulit menyerap air kembali sehingga rawan terbakar (Akbar \& Sukhyar, 2014). Disinyalir bahwa kebakaran lahan gambut di Indonesia secara umum disebabkan oleh aktivitas manusia dalam kegiatan penyiapan lahan untuk pertanian, perkebunan (Thoha, 2006). Pada Februari 2014, hotspot atau titik panas yang terdapat di Riau terpantau pada citra satelit NOAA mencapai 2.208 titik. Pada tanggal 18 Maret 2014 sampai dengan 23 Maret 2014 mencapai 1.398 titik api (Sutopo, 2014) sedangkan pada 1 Juli sampai 23 Oktober 2015 mencapai 1.838 titik api (Panjaitan, 2015). 
Kebakaran pada lahan gambut sangat mempengaruhi perubahan sifat fisik dan kimia gambut dimana keanekaragaman fauna tanah khususnya serangga tanah tersebut tinggal. Jika terjadi kebakaran maka keberadaan dan komposisi faktor-faktor tersebut dapat berubah sehingga menurunkan keberadaan fauna tanah yang khususnya serangga tanah. Menurut Syaufina et al. (2007), kebakaran lahan juga menyebabkan dampak seperti gangguan kesehatan, tercemarnya lingkungan, terganggunya aktivitas ekonomi serta hilangnya keanekaragaman hayati. Keberadaan lahan gambut juga menjadi habitat bagi beberapa spesies, terutama bagi organisme tanah. Salah satu organisme tanah yang memiliki peran penting di lahan gambut adalah makrofauna (Rahmawaty, 2004). Serangga tanah memiliki fungsi meningkatkan kesuburan tanah (Buliyansih, 2005) juga sebagai perombak bahan organik yang tersedia bagi tumbuhan hijau dan serangga tanah juga dapat dijadikan sebagai indikator terhadap kesuburan tanah (Halli et al., 2013). Faktor-faktor yang dapat mempengaruhi keberadaan serangga tanah antara lain dipengaruhi faktor lingkungan, seperti suhu udara, suhu tanah, dan $\mathrm{pH}$ tanah (Rahmawaty, 2004). Penelitian tentang serangga tanah pada lahan kebakaran dan lahan transisi kebakaran pernah dilakukan di Taman Nasional Baluran oleh Halli et al. (2013), hasilnya ditemukan 52 individu di lahan kebakaran dan 282 individu di lahan transisi kebakaran yang terbagi ke dalam 7 ordo dan 16 famili serangga tanah. Abidin (2010), meneliti tentang padang savanna Jemplang (savanna yang tidak terbakar) diperoleh serangga yang berperan sebagai herbivora (11 famili), predator (5 famili), scavenger ( 7 famili), pollinator ( 3 famili) dan parasitoid (3 famili) dan pada Savana Pananjakan (savana yang telah terbakar) diperoleh serangga yang berperan sebagai herbivora (10 famili), predator (6 famili), scavenger (4 famili), pollinator (3 famili) dan parasitoid (3 famili).

Kebakaran pada lahan gambut sangat mempengaruhi perubahan ekosistem lingkungan yang ada termasuk serangga tanah. Mengingat pentingnya peranan serangga tanah dalam menjaga keseimbangan ekosistem tanah maka perlu dilakukan penelitian mengenai keragaman serangga permukaan tanah pada lahan gambut yang terbakar dan lahan hutan lindung.

Penelitian ini bertujuan untuk:mengetahui jenis-jenis serangga permukaan tanah yang ditemukan pada lahan bekas kebakaran dan lahan hutan lindung, membandingkan keanekaragaman serangga permukaan tanah di lahan gambut bekas kebakaran dan lahan hutan lindung dan hasil penelitian diharapkan dapat digunakan sebagai pertimbangan dalam pengelolaan hutan bekas terbakar tersebut.

\section{METODOLOGI}

Penelitian ini dilaksanakan pada bulan Maret sampai Juli 2016, pada lahan gambut bekas kebakaran dan lahan hutan lindung di Desa Kasang Padang, Kecamatan Bonaidarusalam, Kabupaten Rokan Hulu, Provinsi Riau. Identifikasi serangga permukaan tanah dilakukan di Laboratorium Biologi Fakultas MIPA dan Kesehatan Universitas Muhammadiyah Riau.

Alat yang digunakan dalam penelitian ini adalah dissecting set, botol spesimen, mikroskop dissecting, meteran, tali plastik, kantong plastik, gelas plastik ukuran sedang, sterofoam, stick penyangga, pinset, kertas label, buku Identifikasi Serangga Introduction To Study Of Insecta Edition 7th oleh Borror et. al. (2005) dan alat tulis. Bahan yang digunakan dalam penelitian ini adalah air bersih, Alkohol 70\% dan Gliserin.

Proses pengumpulan data secara primer seperti penangkapan serangga dengan metode Pitfall-Trap, dan pengkoleksian serangga dimana titik samplingnya adalah lahan gambut bekas kebakaran 3 tahun yang lalu dan lahan sekitarnya. Identifikasi serangga menggunakan buku acuan Introduction To Study Of Insecta Edition $7^{\text {th }}$ oleh Borror et al. (2005) dan website www. BugGuide.net. Sedangkan pengumpulan data sekunder berupa informasi data lokasi penelitian seperti luas lokasi, kondisi iklim, topografi dan sejarah pengelolaan lahan.

\subsection{Prosedur Kerja}

Langkah persiapan berupa observasi untuk mengetahui gambaran awal tentang lokasi 
penelitian. Pemilihan lokasi penelitian ini di lahan gambut bekas kebakaran tahun 2013 yang lalu dan lahan hutan lindung di Desa Kasang Padang, Kecamatan Bonaidarusalam, Kabupaten Rokan Hulu, Provinsi Riau.

Berdasarkan hasil observasi, maka lokasi pengambilan sampel dibagi menjadi 3 stasiun pengamatan, yaitu :

Stasiun I : Kawasan lahan gambut bekas kebakaran pada tahun 2013 yang belum ditanami tanaman.

Stasiun II : Kawasan lahan gambut bekas kebakaran tahun 2013 yang telah ditanami satu jenis tanaman (Monokultur) yaitu akasia.

Stasiun III : Kawasan hutan lindung yang ditumbuhi oleh bermacam-macam jenis tumbuhan (Heterogen).

Pada masing-masing stasiun dibuat 2 transek, dengan jarak antar transek $150 \mathrm{~m}$. Pada masingmasing transek dibuat 3 plot secara zig zag dengan jarak antar plot $50 \mathrm{~m}$, dengan ukuran plot $25 \mathrm{~m} \times 25 \mathrm{~m}$.

Teknik pengambilan sampel dilakukan dengan metode Pitfall-trap (Michael, 1994). Perangkap jebakan ini menggunakan gelas plastik yang biasa digunakan sebagai gelas minum dengan ukuran garis tengah dasar $5,5 \mathrm{~cm}$ dan tinggi $10 \mathrm{~cm}$. Perangkap jebakan dipasang dengan cara menanamkan gelas di tanah kemudian dipasang sterofoam dengan jarak 10 $\mathrm{cm}$ dari gelas. Gelas diisi Alkohol 70\% sebanyak $3 / 4$ gelas untuk pengawetan serangga permukaan tanah yang terjebak dan Gliserin 3 tetes untuk mengurangi penguapan Alkohol (Karmana, 2010), kemudian diletakkan pada masing-masing daerah sampling. Perangkap dipasang secara diagonal sebanyak 5 buah pada masing-masing plot pada ketiga lokasi penelitian. Pengumpulan serangga dilakukan 2 hari sekali selama 1 bulan.

\subsection{Identifikasi Serangga}

Serangga permukaan tanah diidentifikasi berdasarkan ciri-ciri morfologi (morfospesies) menggunakan buku Introduction To Study Of Insecta Edition $7^{\text {th }}$ oleh Borror et. al. (2005) dan website www.BugGuide.net.

\subsection{Pembuatan Insektarium}

Serangga yang tertangkap di lapangan, kemudian diawetkan dengan cara basah. Serangga dimasukkan ke dalam botol koleksi yang telah diberi Alkohol 70\% dan diberi label (nama genus, lokasi, tanggal lokasi, nama kolektor).

\subsection{Analisis Data}

Analisis data mengikuti beberapa formula berikut ini yaitu :

\section{Indeks Keanekaragaman (Odum, 1993)}

Dimana: $\mathrm{H}^{\prime}=$ Indeks Keanekaragaman. $\mathrm{ni}=$ Jumlah individu dalam genus ke-I (per plot).

$\mathrm{N}=$ Jumlah total individu (per plot).

Dengan kriteria:

Jika $\mathrm{H}<1=$ Keanekaragaman rendah.

Jika $1<\mathrm{H} 3=$ Keanekaragaman sedang.

Jika $\mathrm{H}>3$ = keanekaragaman tinggi.

\section{Indeks Dominansi (Odum, 1993)}

$$
\mathrm{C}=\sum\left(\frac{\mathrm{ni}}{\mathrm{N}}\right) 2
$$

Dimana : $\mathrm{C}=$ Indeks Dominansi. $\mathrm{ni}=$ Jumlah individu setiap genus I

(per plot)

$$
\mathrm{N}=\text { Jumlah total individu seluruh }
$$

genus (per plot)

Dengan kriteria :

Jika nilai $\mathrm{C}<0,50=$ Dominansi rendah

Jika nilai $0,50<\mathrm{C} 0,75=$ Dominansi sedang

Jika nilai $0,75<\mathrm{C}<1=$ Dominansi tinggi

\section{Indeks Kesamaan (Odum, 1993)}

Dimana : IS = Indeks Kesamaan Sorensen.

$\mathrm{D}=$ jumlah suku serangga yang menempati di ketiga habitat.

$\mathrm{A}=$ jumlah suku serangga yang ada di habitat pertama.

$B=$ jumlah suku serangga yang

ada di habitat kedua. 
$\mathrm{C}=$ jumlah suku serangga yang ada di habitat ketiga.

Dengan kriteria:

Jika nilai IS $<0,75=$ kesamaan rendah

Jika nilai IS $>0,75=$ kesamaan tinggi

\section{HASIL DAN PEMBAHASAN}

Keanekaragaman serangga permukaan tanah pada lahan gambut bekas kebakaran dan hutan lindung dapat dilihat pada Tabel 3.1.

Tabel 3.1 Keanekaragaman Serangga Permukaan Tanah pada Lahan Gambut Bekas Kebakaran dan Hutan Lindung

\begin{tabular}{|c|c|c|c|c|c|c|}
\hline \multirow[t]{2}{*}{ No } & \multicolumn{3}{|c|}{ Nama Jenis Serangga Seluruh Stasiun } & \multicolumn{3}{|c|}{$\begin{array}{l}\text { Jumlah } \\
\text { Individu/Stasiun }\end{array}$} \\
\hline & Ordo & Famili & Genus & I & II & III \\
\hline \multirow[t]{2}{*}{1} & \multirow[t]{2}{*}{ Blattaria } & \multirow{2}{*}{ Blattidae } & Blattela & & 7 & 1 \\
\hline & & & Platyzosteria & 8 & 538 & 0 \\
\hline \multirow[t]{4}{*}{2} & Coleoptera & \multirow[t]{2}{*}{ Carabidae } & Branchinus & 0 & 0 & 15 \\
\hline & & & Nebria & 0 & 0 & 3 \\
\hline & & Scarabidae & Oryctes & 1 & 0 & 0 \\
\hline & 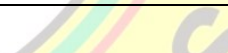 & Scolytidae & Pityogenes & 14 & 13 & 0 \\
\hline 3 & Diptera & Stratiomyidae & Hermetia & 1 & 0 & 0 \\
\hline 4 & Dermaptera & Forficulidae & Forficula & 26 & 18 & 22 \\
\hline 5 & Hemiptera & Reduviidae & Zelus & 2 & 0 & 0 \\
\hline \multirow[t]{4}{*}{6} & Hymenoptera & \multirow[t]{2}{*}{ Formicidae } & Anoplolepis & 37 & 1269 & 951 \\
\hline & +6 & & Coтропитиs & 55 & 156 & 48 \\
\hline & & & Odontomachus & 19 & 26 & 31 \\
\hline & 2 & & Pheidologeton & 0 & 4 & 0 \\
\hline \multirow[t]{3}{*}{7} & Orthoptera & Gryllidae & Gryllus & 48 & 55 & 41 \\
\hline & & Gryllotalpidae & Gryllotalpa & 0 & 0 & 1 \\
\hline & $P$ & Tettigonidae & Tettigonia & 6 & 0 & 12 \\
\hline \multicolumn{2}{|c|}{ Total Individu } & 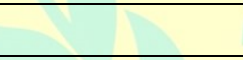 & 1 & 229 & 2086 & 1125 \\
\hline \multicolumn{3}{|c|}{ Total Genus } & $\overline{7}$ & 12 & 9 & 10 \\
\hline \multicolumn{4}{|c|}{ Nilai Indeks Keanekaragaman } & $\mathbf{0 , 8 7}$ & 0.48 & $\mathbf{0 , 3 1}$ \\
\hline \multicolumn{4}{|c|}{ Nilai Indeks Dominansi } & $\mathbf{0 , 1 5}$ & $\mathbf{0 , 4 4}$ & $\mathbf{0 , 7 1}$ \\
\hline \multicolumn{4}{|c|}{ Nilai Indeks Kesamaan } & $58 \%$ & 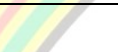 & \\
\hline
\end{tabular}

Hasil penelitian tentang serangga permukaan tanah yang dilakukan di Desa Kasang Padang dapat dilihat pada Tabel 3.1, dimana pada Stasiun I ditemukan 229 individu dengan 12 spesies, Stasiun II ditemukan 2086 individu dengan 9 spesies, dan Stasiun III ditemukan sebanyak 1140 individu dengan 10 spesies. Nilai Indeks Keanekaragaman serangga permukaan tanah pada Stasiun I yaitu $(0,87)$, Stasiun II yaitu $(0,48)$, Stasiun III yaitu $(0,31)$. Sedangkan nilai Indeks Dominansi pada Stasiun I adalah $(0,156)$, Stasiun II $(0,443)$, dan pada Stasiun III sebesar $(0,719)$.
Nilai Indeks Kesamaan untuk 3 Stasiun yaitu $58 \%$.

Berdasarkan Tabel 3.1 di atas, dapat dilihat bahwa pada Stasiun I ditemukan jumlah individu yang paling sedikit ditemukan pada Stasiun I yaitu 229 individu. Hal ini dikarenakan Stasiun I memiliki kandungan bahan organic yang sedikit akibat kebakaran yang menyebabkan terganggunya ekosistem serangga tanah. Menurut Vembrianto et al. (2015), bahan organik yang terbakar pada tanah gambut menyebabkan COrganik yang berada di atas permukaan semakin berkurang terutama di lapisan atas permukaan. 
Lebih lanjut Ruslan (2009), menyatakan bahwa keberadaan serangga permukaan tanah sangat tergantung pada ketersediaan energi dan sumber makanan untuk melangsungkan hidupnya, seperti bahan organik dan biomassa hidup yang semuanya berkaitan dengan aliran siklus karbon dalam tanah, dengan ketersediaan energi dan hara bagi serangga permukaan tanah tersebut, maka perkembangan dan aktivitas serangga permukaan tanah akan berlangsung baik.

Jumlah serangga permukaan tanah yang paling banyak ditemukan adalah pada Stasiun II yaitu 2086 individu dengan mayoritas Genus Anoplolepis dan Platyzosteria. Banyaknya jumlah Genus Anoplolepis dan Platyzosteria diduga ada hubungannya dengan kondisi Stasiun II. Pada Stasiun II ini merupakan lahan gambut bekas kebakaran tahun 2013 yang lalu, namun saat ini telah ditanami oleh tanaman perkebunan akasia (Acacia crassicarpa) secara monokultur. Pada Stasiun II, daun dari tanaman akasia yang berjatuhan dibiarkan oleh pengurus perkebunan menumpuk di bawah pohon yang secara langsung atau tidak langsung dapat sebagai tempat berlindung dan sebagai makanan bagi serangga tanah. Menurut Sugiyarto et al. (2002), bahwa serasah bisa berfungsi sebagai sumber energi bagi komunitas hewan tanah. Bagi fauna tanah, serasah juga berfungsi sebagai tempat berlindung dari cahaya matahari langsung maupun dari serangan predator. Menurut Srinivasan (2009) dan Ayu et al. (2015), Platyzosteria merupakan serangga pemakan kayu (Xylophagous) yang menghabiskan sebagian besar hidupnya di dalam rongga-rongga kayu mati yang dibuatnya dan memakan kayu untuk sumber nutrisinya. Platyzosteria banyak ditemukan pada sampah, vegetasi, rumah maupun tanah. Lebih lanjut Latumahina et al. (2013), menyatakan bahwa Anoplolepis banyak ditemukan pada habitat yang terganggu, permukiman, daerah perkotaan, perkebunan, padang rumput, savana, dan areal hutan yang menyebar melalui tanah dan kayu. Jadi banyaknya jumlah individu Genus Anoplolepis dan Platyzosteria diduga ada hubungannya dengan banyaknya serasah akasia.

Adapun serangga permukaan tanah yang paling sedikit ditemukan di Stasiun I adalah
Oryctes dan Hermetia. Serangga permukaan tanah yang ditemukan pada Stasiun III adalah Gryllotalpa yang masing-masing ditemukan sebanyak 1 individu. Genus Oryctes dan Gryllotalpa bersifat mobile sehingga sering berpindah tempat untuk mencari makan. Menurut Ramlan et al. (2010), ordo-ordo Coleoptera, Ortoptera merupakan fitofag yaitu merupakan serangga yang umum ditemukan pada tanaman pertanian yang dibudidayakan. Selanjutnya menurut Setiawati et al. (2005), bahwa Gryllotalpa banyak ditemukan pada tanaman kentang (Solanum tuberosum L), bawang merah (Allium cepa), tembakau (Nicotiana tabacum), jagung (Zea mays), dan singkong (Manihot utilissima).

Genus Hermetia ditemukan sedikit kerena Hermetia biasanya menghabiskan hidupnya di permukaan tanah dalam tingkat larva, sedangkan dewasa berada di permukaan tanah hanya untuk mencari makan. Menurut Ma'arif et al. (2013), keberadaan Ordo Diptera di tanah berhubungan dengan kebiasaan dan perilaku makan serangga yang sebagian merupakan pemakan berbagai tumbuhan maupun zat organik yang membusuk selain itu juga memakan cairancairan hewan.

Serangga permukaan tanah yang paling banyak ditemukan di lokasi penelitian yaitu genus Anoplolepis dari Famili Formicidae dengan jumlah total individu 2257, genus ini ditemukan hampir di setiap stasiun, hal ini terjadi dikarenakan Famili Formicidae (semut) adalah satu kelompok organisme yang sangat banyak dan bersifat koloni dan mencari makan keluar sarang sehingga banyak semut yang masuk ke dalam jebakan. Menurut Latumahina et al. (2013), bahwa Anoplolepis memiliki jumlah individu terbanyak karena memiliki tempat mencari makan yang luas, sehingga disebut sebagai predator pemulung karena memangsa berbagai fauna di serasah dan kanopi. Selanjutnya dari hasil penelitian Yulminarti et al. (2012), juga ditemukan Formicidae sebagai serangga yang paling banyak. Tersedianya serasah dengan jumlah yang banyak merupakan faktor pendukung melimpahnya spesies ini. Kondisi habitat tanah gambut merupakan habitat yang terdiri dari timbunan bahan organik yang 
belum terdekomposisi sempurna yang terdiri dari tumbuhan yang telah mati seperti dedaunan, akarakar, ranting, bahkan batang pohon lengkap, dan telah terakumulasi selama ribuan tahun.

Nilai Indeks Keanekaragaman (H') dari ketiga stasiun yang memiliki nilai tertinggi terdapat pada Stasiun I yaitu 0,87 yang termasuk golongan sedang artinya kondisi ekosistem cukup untuk mendukung kehidupan dari serangga permukaan tanah. Hal ini dikarenakan Stasiun I mulai terjadi suksesi sehingga banyak sumber makanan untuk serangga tanah seperti tanaman ilalang (Imperata cylindrica $\mathrm{L}$,), pakis, putri malu (Mimosa pudica L.), senduduk (Melastoma sp.) yang merupakan tanaman pionir. Berryman dalam Rahmawaty (2004), menyatakan bahwa serangga berperan penting dalam proses suksesi dan menjaga kestabilan ekosistem hutan. Fahaludin et al. (2015) menyatakan, lahan gambut memiliki banyak jenis tumbuhan yang merupakan salah satu habitat untuk serangga seperti seduduk (Melastoma sp.), putri malu (Mimosa pudica L.), ilalang (Imperata cylindrica L,), dan pakis (Stenochama polushis L). Lebih lanjut Wibowo \& Sylvia (2014), menjelaskan bahwa banyaknya tumbuhan bawah (rumput-rumputan) menjadi sumber makanan bagi serangga tanah. Nilai Indeks Keanekaragaman serangga permukaan tanah pada Stasiun II yaitu 0,48 menunjukan nilai Indeks Keanekaragaman yang lebih rendah dibandingkan dengan Stasiun I. Hal ini dikarenakan Stasiun II sudah dijadikan sebagai kawasan alih fungsi sebagai kawasan perkebunan monokultur yang ditanami oleh tanaman akasia yang mempengaruhi ketersediaan sumber makanannya. Menurut Latumahina \& Anggraeni (2010), alih fungsi kawasan dapat menjadi factor pembatas yang mempengaruhi ketersediaan sumber pakan, tempat beraktivitas, tempat berlindung dan tempat reproduksi bagi serangga dimana apabila habitat suatu jenis serangga mengalami gangguan, maka serangga akan berpindah mencari habitat baru yang sesuai dengan kebutuhannya. Stasiun III merupakan stasiun dengan nilai Indeks Keanekaragaman paling rendah dengan nilai sebesar 0,31 . Stasiun III merupakan kawasan hutan lindung yang berada dekat dengan warga. Beberapa tahun ini masyarakat sekitar mulai menjadikan hutan lindung tersebut sebagai tempat mencari kayu, pelebaran lahan dan dijadikan lahan pertanian sehingga ekosistem kawasan tersebut terganggu yang secara langsung tidak langsung akan mempengaruhi kehidupan serangga di ekosistem tersebut. Menurut Latumahina (2011), konversi hutan lindung akan berpengaruh terhadap struktur, komposisi dan fungsi dari hutan yang akan mengakibatkan kerusakan biotik dan abiotik termasuk serangga tanah yang akan berpindah tempat mencari habitat baru

\section{Nilai Indeks Dominansi}

Nilai Indeks Dominasi digunakan untuk mengetahui ada atau tidak spesies tertentu yang mendominasi pada suatu ekosistem. Berdasarkan hasil yang didapat, Nilai Indeks Dominansi disetiap Stasiun I,II, dan III yaitu 0,$156 ; 0,443$; dan 0,719. Menurut Odum (1993), apabila indeks Simpson (C) berkisar antara $0-0.5$ maka dominansi tergolong rendah artinya keadaan yang telah mengalami gangguan artinya, bila $\mathrm{C}>$ 0,5-0.75 maka dominansi tergolong sedang yang artinya keadaan yang telah mulai stabil, dan apabila $\mathrm{C}>0,75-1$ maka dominansi tergolong tinggi artinya keadaan yang belum menggalami gangguan dan pencemaran. Jika dilihat dari nilai Indeks Dominansi serangga tanah pada Stasiun I tergolong rendah yang artinya tidak ada genus yang lebih mendominansi dalam komunitas tersebut. Hal ini diduga karena Stasiun I merupakan lahan gambut bekas kebakaran tahun 2013 yang lalu, artinya telah terjadi gangguan pada ekosistem yang berakibat pada serangga permukaan tanah. Sejalan dengan terjadinya pemulihan lahan yang telah terbakar menjadi lahan yang stabil maka serangga permukaan tanah juga akan berangsur-angsur mendatangi tempat tersebut dan menjadikannya sebagai habitat baru bagi serangga permukaan tanah. Nilai Indeks Dominansi pada Stasiun II tergolong rendah menuju sedang, diduga karena stasiun ini walaupun berada pada lahan gambut bekas kebakaran 3 tahun yang lalu tetapi sudah di tanami dengan tanaman akasia yang mungkin menyebabkan serangga tanah di stasiun ini mulai menjadi stabil. Menurut Rusnaningsih (2012) 
menyatakan bahwa, apabila Indeks Dominansinya mendekati nol maka dalam ekosistem tersebut tidak ada spesies yang secara ekstrim mendominansi spesies yang lainya, sehingga dapat dikatakan struktur komunitas dalam keadaan stabil dan tidak terjadi tekanan ekologis yang berlebihan terhadap biota dalam ekosistem tersebut. Nilai Indeks Dominasi tergolong tinggi (stabil) pada Stasiun III, diduga karena stasiun ini walaupun berada pada hutan lindung yang ekosistemnya sudah mulai sedikit terganggu, seperti gangguan pelebaran jalan, masyarakat yang mencari kayu dan dijadikan lahan pertanian tetapi gangguan tersebut belum sampai mengakibatkan terganggu kehidupan serangga tanah. Pada Stasiun III terdapat 2 famili yang mendominasi yaitu famili Formicidae dan Gryllidae.

Nilai Indek Kesamaan Sorensen dari ketiga stasiun didapat adalah 58\% yang termasuk kategori rendah artinya didapatkan sedikit genus yang sama pada ketiga stasiun, artinya genus yang ditemukan pada tiga lokasi adalah berbeda. Hal ini kemungkinan berhubungan dengan kondisi ketiga habitat masing-masing Stasiun yang berbeda menyebabkan perbedaan organisme yang menyusun habitat tersebut. Menurut Suhardjono et al. dalam Ruslan (2009), bahwa faktor vegetasi dapat mempengaruhi penyediaan habitat bagi serangga permukaan tanah. Perbedaan terdapat pada individu-individu tersebut walaupun berada dalam satu spesies. Variasi organisme ini terjadi karena adanya beberapa faktor, yaitu faktor internal dan faktor eksternal. Faktor eksternal dapat berupa sinar matahari, cahaya, makanan, kelembaban. Sedangkan faktor internal berupa adanya pengaruh lingkungan (Odum, 1993). Lebih lanjut Erawati \& Kahono (2010), menyatakan bahwa Indeks Kesamaan Sorensen nilainya 0 sampai dengan 1, nilai 1 berarti jumlah spesies yang ditemukan di tiga Stasiun adalah sama dan nilai 0 berarti jumlah spesies yang ditemukan di tiga Stasiun adalah berbeda sama sekali. Serangga yang ditemukan pada ketiga stasiun adalah Blattela, Forficula, Anoplolepis, Compontus, Odontomachus, dan Gryllus. Hal ini dikarena ke6 genus ini termasuk kedalam serangga permukaan tanah yang individunya cukup banyak dan tersebar luas. Menurut Borror et al. (2005), bahwa Blattela ditemukan di bawah reruntuhan daun dan kulit kayu, atau dengan di bawah kayu gelondongan yang jatuh. Forficula menyukai tempat sejuk, seperti di bawah batu, celah, atau lubang bawah tanah, di bawah batang pohon, di balik kulit kayu, dan juga di bawah sampah (Iqbal, 2013). Latumahina et al. (2013), menyatakan Anoplolepis, Compontus, Odontomachus banyak ditemukan pada habitat yang terganggu,

permukiman, daerah perkotaan, perkebunan, padang rumput, savana, dan areal hutan yang menyebar melalui tanah dan kayu. Selanjutnya Gryllus banyak ditemukan di bawah batu-batuan, reruntuhan pohon atau dalam tanah (Mandala, 2012)

\section{KESIMPULAN}

1. Serangga permukaan tanah yang ditemukan sebanyak 16 genus, yaitu Blattela, Platyzosteria, Branchinus, Nebria, Oryctes, Pityogenesis, Hermetia, Forficula, Zelus, Anoplolepis, Componutus, Odontomachus, Pheidologeton, Gryllus, Gryllotalpa, dan Tettigonia.

2. Serangga permukaan tanah di lahan gambut bekas kebakaran ditemukan sebanyak 13 genus yaitu Blattela, Platyzosteria, Pityogenesis, Oryctes, Forficula, Anoplolepis, Componutus, Odontomachus, Zelus, Hermetia, Pheidologeton, Tettigonia dan Gryllus.

3. Serangga permukaan tanah di lahan hutan lindung ditemukan 10 genus yaitu Blattela, Branchinus, Nebria, Forficula, Anoplolepis, Componutus, Odontomachus, Gryllus, Gryllotalpa dan Tettigonia.

4. Nilai Indeks Keanekaragaman serangga permukaan tanah pada Stasiun I yaitu 0,87 (sedang), Stasiun II yaitu 0,48 (rendah), Stasiun III yaitu 0,31 (rendah).

5. Nilai Indeks Dominansi pada Stasiun I adalah 0,156 (rendah), Stasiun II dengan nilai 0,443 (rendah), dan pada Stasiun III didapat nilai dominansi sebesar 0,719 (sedang). 
6. Nilai Indeks Kesamaan untuk 3 stasiun yaitu $58 \%$ (rendah).

\section{DAFTAR PUSTAKA}

Abidin, Z. 2010. Studi Keragaman Serangga di Vegetasi Savana Taman Nsional Bromo Tengger Semeru (TN-BTS). Skripsi. Jurusan Biologi, Fakultas Sains dan Teknologi, Universitas Islam Negeri (UIN), Maulana Ibrahim Malang.

Akbar, A dan Sukhyar, F. 2014. Kebakaran Hutan dan Lahan Rawa Gambut Penyebab Faktor Pendukung dan Alternatif Pengelolaannya. Balai Penelitian Kehutanan Banjarbaru, Kalimantan Selatan.

Ayu, N. D., Lutfi Y., dan Nimas P,. 2015. Sistemika Terjadinya Penyakit Oleh Vektor Kecoa. Universitas Negeri Semarang.

Borror, DJ., Long Dm, dan Triplehorn CA. 2005. An Introduction to the Study of Insects. 7th edition. New York: Saunders College Publishing.

Buliyansih, A, 2005. Penilaian Dampak Kebakaran terhadap Makrofauna Tanah dengan Metode Forest Health Monitoring (FHM). Skripsi. Departemen Manajemen Hutan Fakultas Kehutanan, Institut Pertanian Bogor.

Erawati N. V. dan Sih Kahono. 2010. Keanekaragaman dan Kelimpahan Belalang

dan Kerabatnya (Orthoptera) pada Dua Ekosistem Pegunungan di

Taman Nasional Gunung Halimun-Salak. Jurnal Entomol. Indon September 2010, Vol. 7 , No. 2, 100-115.

Falahudin I. Delima E. M. dan Indah. 2015. Diversitas Serangga Ordo Orthoptera Pada Lahan Gambut Di Kecamatan Lalan Kabupaten Musi Banyuasin. Jurnal Bioilmi Vol. 1 No. 1 Edisi Agustus 2015.

Halli, M., Ida dan Bagyo Y. 2014. Diversitas Arthropoda Tanah di Lahan Kebakaran dan Lahan Transisi Kebakaran Jalan HM
36 Taman Nasional Baluran. Jurnal Biotropika Vol. 2 No. 12014.

Iqbal. 2013. Pengamatan Morfologi Cecopet (Ordo :Dermaptera) Pada Tanaman Kelapa, Salak Dan Sawi Putih. Jurusan Hama dan Penyakit Tumbuhan Fakultas Pertanian Universitas Hasanuddin Makassar.

Karmana, I. W. 2010. Analisis Keanekaragaman Epifauna dengan Metode Koleksi Pitfall Trap di Kawasan Hutan Cagar Malang. Jurnal Ganec Swara Vol 4 No. 1: 1-5. Kecamatan Bonai Darussalam Dalam Angka Tahun 2013. Badan Pusat Statistik Kabupaten Rokan Hulu.

Latumahina. F. S dan Anggraeni. I. 2010. Diversitas Coleoptera Dalam Kawasan Hutan Lindung Sirimau Kota Ambon. Jurnal Agroforestri 24-25 September 2010.

Latumahina F. S. 2011. Pengaruh Alih Fungsi Lahan Terhadap Keanekaragaman Semut Alam Hutan Lindung Gunung NonaAmbon. Jurnal Agroforestri Volume VI Nomor 1 Maret 2011.

Latumahina F. S, Musyafa, Sumardi, dan Nugroho S. P. 2013. Keragaman Semut Pada Areal Pemukiman dalam Hutan Lindung Sirimau Kota Ambon. Jurnal Agroforestri VIII Nomor 4 Desember 2013.

Ma'arif S, Suartini, dan Ginantra. 2013. Diversitas Serangga Permukaan Tanah Pada Pertanian Hortikultura Organik di Banjar Titigalar, Desa Bangli, Kecamatan Baturiti, Kabupaten Tabanan-Bali. Jurnal Biologi XVIII (1) : $28-32$

Mandala A. N. 2012. Perilaku Nyanyian Jangkrik (Gryllus Sp.). Program Studi Biologi Sekolah Ilmu Dan Teknologi Hayati Institut Teknologi Bandung. Bandung.

Michael, P. 1994. Metode ekologi untuk penyelidikan ladang dan laboraturium. Terjemahan dari Ecological Methods For Field and laboratory investigations, oleh Yanti R, K dan Sahati S., Universitas Indonesia Press :Jakarta. 
Mubekti. 2011. Studi Pewilayahan dalam Rangka Pengelolaan Lahan Gambut Berkelanjutan Di Provinsi Riau. Jurnal Sains dan Teknologi Indonesia Vol. 13, No. 2, Agustus 2011 Hlm.88-94.

Odum, P. E. 1993. Dasar-dasar Ekologi Edisi ke tiga. Yogyakarta : UGM Press.

Panjaitan, R.B. 2015. Status Terkini Kabut Asap dari Karlahut. Direktur Pengendalian Kebakaran Hutan dan Lahan, Kementerian LHK.

Profil Desa Kasang Padang. 2015. Data Awal Rencana Pemetaan.

Rahmawaty. 2004. Studi Keanekaragaman Mesofauna Tanah di Kawasan Hutan Wisata Alam Sibolangit (Desa Sibolangit, Kecamatan Sibolangit, Kabupaten Daerah Tingkat II Deli Serdang, Propinsi Sumatera Utara). Jurusan Kehutanan Program Studi Manajemen Hutan Fakultas Pertanian. Universitas Sumatera Utara.

Ramlan, Nurjanani, dan Sjafaruddin, M. 2010. Kajian Teknologi Pengelolaan Hama Kopi Arabika Ramah Lingkungan. Balai Pengkajian Teknologi Pertanian Sulawesi Selatan. Prosiding Seminar Ilmiah dan Pertemuan Tahunan PEI dan PFI XX Komisariat Daerah Sulawesi Selatan, 27 Mei 2010.

Ruslan, H. 2009. Komposisi dan Keanekaragaman Serangga Permukaan Tanah pada Habitat Hutan Homogen dan Heterogen di Pusat Pendidikan Konservasi Alam (Ppka) Bodogol, Sukabumi, Jawa Barat. Jurnal Vis Vitalis, Vol. 02 No. 1, Maret 2009.

Rusnaningsih. 2012. Struktur Komunitas Gastropoda Dan Studi Populasi Cerithidea obtuse (Lamarck 1822) Di HUtan Mangruve Pangkalan Babu, Kabupaten Tanjung Jabung Barat, Jambi. Tesis. Fakultas Matematika Dan Ilmu Pengetahuan Alam Universitas Indonesia.

Setiawati, P., Bagus K. U, dan Agus M. 2005. Pengenalan dan Pengendalian Hamahama Penting pada Tanaman Cabai
Merah. Balai Penelitian Tanaman Sayuran Pusat Penelitian dan Pengembangan Hortikultura Badan Penelitian dan Pengembangan Pertanian. Srinivasan. R.2009. Insect And Mite Pests On Eggplant. Avrdc - The World Vegetable Center.

Sugiyarto, Wijaya, D., dan Suci, Y.R. 2002. "Biodiversitas Hewan Permukaan Tanah Pada Berbagai Tegakan Hutan Disekitar Gua Jepang, BKPH Nglerak, Lawu Utara, Kab.Karang Anyar". Jurnal Biodiversitas 3(1):196-200

Sutopo, P.N. 2014. GEMA BNPB Ketangguhan Bangsa dalam Menghadapi Bencana. VOL. 5 NO. 1. ISSN 2088-6527 MEI 2014.

Syaufina, L., Noor F.H dan Asri B. 2007. Keanekaragaman Arthropoda Tanah di Hutan Pendidikan Gunung Walat. Media Konservasi Vol. XII, No. 2 Agustus 2007 : $57-66$.

Thoha , A.S. 2006. Penggunaan Penginderaan Jauh untuk Deteksi Kebakaran Gambut Di Kabupaten Bengkalis Propinsi Riau. Penomena Forestry Science Journal Volume. 2. Nomor. 2 September 2006. ISSN 18296343

Vembrianto, N. Defri Y. dan Evi S. 2015. Karakteristik Ekologi Lokasi Kebakaran Hutan Dan Lahan Di Desa Rantau Bais Kecamatan Tanah Putih Kabupaten Rokan Hilir. Universitas Riau. Jurnal Jom Faperta Vol. 2 No. 1 Februari 2015.

Wibowo, C dan Sylvia D.W. 2014. Keanekaragaman Insekta Tanah pada Berbagai Tipe Tegakan di Hutan Pendidikan Gunung Walat dan Hubungannya dengan Peubah Lingkungan. Jurnal Silvikultur Tropika Vol. 05 No. 1 April 2014, Hal 33-42 ISSN: 2086-82.

Yulminarti, Siti. S, Tati dan Subahar. 2012. Jumlah Jenis dan Jumlah Individu Semut di Tanah Gambut Alami dan Tanah Gambut Perkebunan Sawit di Sungai Pagar, Riau. Jurnal Biospecies, Volume 5 No 2, Juli 2012, Hal 21-27. 